\title{
ÉCFRASE E EVIDÊNCIA
}

\author{
Melina RodolPHO*
}

Universidade de São Paulo

\begin{abstract}
Resumo. A écfrase é um procedimento descritivo empregado em textos retóricos e poéticos desde a Antiguidade Clássica, cuja finalidade é trazer o conteúdo descrito diante dos olhos por meio de recursos que tornem a imagem intensamente vivaz. Usualmente, é relacionada a outros procedimentos retóricos que contribuem para produzir o mesmo efeito de visualização, tal como a enargia e a evidência. Para tentar dirimir as dúvidas em relação à definição da écfrase e compreender a associação da écfrase com algumas figuras retóricas, apresenta-se aqui uma breve pesquisa com base em fontes retóricas antigas, tais como Aristóteles, os progymnásmata, Cícero e Quintiliano, e também em estudos recentes a respeito do tema. Alguns exemplos do uso da écfrase em textos antigos são analisados para verificar os recursos que possibilitam a visualização do discurso verbal.
\end{abstract}

Palavras-chave. Écfrase; evidência; enargia; fantasia; retórica.

D.O.I. 10.11606/issn.2358-3150.v18i1p94-113

INVESTIGAREMOS O CONCEITO DA ÉKPHRASIS E QUAL É A RELAÇÃO DESTA COM a euidentia. Doravante, adotaremos écfrase para o termo grego ékphrasis

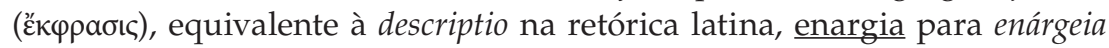

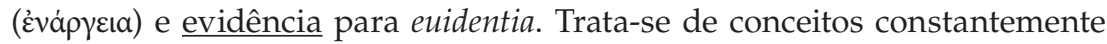
apresentados como correspondentes, no entanto, verificaremos que a nomeação de tais procedimentos e suas definições não são de fato tão exatas.

Ao iniciar a pesquisa ${ }^{1}$ concernente ao tema, tinha em vista diferenciar a écfrase da evidência porque são geralmente confundidas; desse modo, justifica-se a aparente incoerência do título desse artigo que traz como par um vocábulo grego e outro latino para conceitos distintos. A partir da investigação em variadas fontes antigas, parecerá mais lógico colocar os pares "écfrase e enargia" ou "descrição e evidência", ainda assim, mantivemos o

\footnotetext{
* Doutora na área de Língua e Literatura Latina (Letras Clássicas) pela Universidade de São Paulo (2014), com bolsa Capes.

* Artigo recebido em 05.ago.2015 e aceito para publicação em 31.out.2015.

${ }^{1}$ Este artigo é resultado da apresentação no II Colóquio "Visões da Antiguidade" - Vertentes da Ékphrasis (2011) e apresenta um panorama da pesquisa de Mestrado "Écfrase e Evidência nas Letras Latinas: Doutrina e Práxis" (2010), com bolsa financiada pelo CNPq.
} 
paralelo no título justamente para manifestar a dificuldade existente ao determinar a nomenclatura e traçar os limites entre tais procedimentos.

\section{1. ÉKPHRASIS: INVESTIGAÇÃO DO CONCEITO}

A écfrase, segundo definição no Manual de Retórica Literaria de Lausberg $^{2}, \S 1133$, consiste no processo descritivo detalhado de uma pessoa ou objeto com a finalidade de produzir a enargia. Nesse mesmo manual encontramos a definição da evidência, §810, como a descrição viva e detalhada de um objeto, mediante a enumeração de suas particularidades sensíveis, quer sejam reais ou inventadas pela fantasia.

A enargia, ou evidência, pode ser considerada uma figura de pensamento cuja finalidade é conferir vivacidade à imagem verbal. Ainda que o estudo da écfrase quase sempre esteja relacionado à enargia, não é este o único meio capaz de gerar enargia, tal como a metáfora, que é o tropo mais bem-conceituado entre os teóricos antigos. A metáfora produz enargia por meio da comparação, pois esta não funciona sem um exercício imaginativo que presentifica, de certa maneira, o objeto, é o que Aristóteles chama de fantasia ${ }^{3}$. Contudo, a écfrase nos desperta o interesse em razão de seu histórico, visto ser frequentemente associada à construção de imagens que, por sua vez, representam objetos inexistentes de maneira absolutamente crível.

A écfrase só foi sistematizada por autores de progymnásmata na Roma Imperial (Teão, Aftônio, Hermógenes) e também reutilizada de forma variada por autores ditos da Segunda Sofística (Filóstrato, Luciano, Calístrato, Filóstrato, o Jovem, entre outros), no entanto, é possível observar que o mecanismo já vinha sendo utilizado em períodos anteriores, como veremos adiante.

Durante a Segunda Sofística, algumas obras empregam a écfrase como gênero de descrição de obras de arte, tais como os Eikones de Filóstrato, as Ekphráseis de Calístrato, além de romances sofísticos. Conforme destaca Hansen ${ }^{4}$ em seu texto "As categorias epidíticas da ékphrasis", tratar a écfrase simplesmente como gênero voltado às obras de arte, uma das acepções atribuída por alguns estudiosos, seria incoerente quando relacionado ao escudo de Aquiles, na Ilíada, já que não se trata da descrição isolada de um objeto e o poema precede às teorias de gênero.

\footnotetext{
${ }^{2}$ Lausberg 1966.

${ }^{3}$ Arist. De An. 427b-428b.

${ }^{4}$ Hansen 2006.
} 
Hélio Teão - autor de progymnásmata do século 1 d.C. - inclui a écfrase entre os exercícios de retórica que devem ser ensinados aos jovens. Segundo Teão, §118, a écfrase é uma composição periegética que expõe em detalhe e apresenta diante dos olhos de maneira evidente o objeto. Há uma tipologia da écfrase apresentada por Teão condizente com a teorização de outros autores:

- Personagens (prosopa): como fez Homero, por exemplo, "Era encurvado, de cute queimada e os cabelos bem crespos, / e tinha o nome de Euríbates". ${ }^{5}$ Os animais também são inseridos nessa categoria.

- Ações (pragmata): guerra, paz, fome, epidemia, terremoto etc.

- Lugares (topoi): praias, cidades, ilhas, desertos etc.

- Épocas/tempo (chronoi): estações do ano e festividades.

- Modos (tropoi): quais são os equipamentos, armas e máquinas de guerra, em relação aos preparativos de cada um, como no canto 18 da Ilíada.

Teão cita ainda, no §119, que a écfrase pode ser mista como, por exemplo, no combate noturno da História da Guerra do Peloponeso de Tucídides, 7.44 - a noite é uma circunstância temporal e o combate é uma ação.

A écfrase apresenta duas virtudes essenciais mencionadas em vários autores de exercícios de retórica: a clareza, saphéneia, e a vivacidade, cujo termo é enárgeia, para que quase se veja o conteúdo da descrição; além disso, a exposição deve adaptar-se ao tema, sem estender-se em aspectos desnecessários.

Teão propõe que haja uma ordem nas ações processadas por meio da descrição, tal como no caso da guerra em que se examinam primeiramente as circunstâncias anteriores ao evento (a organização das tropas, os gastos, os temores, a devastação do país), em seguida os fatos da guerra (ferimentos, mortes, duelos) e, por fim, as consequências (a conquista e a escravidão de uns e a vitória de outros). Com esse princípio, prioriza-se certa unidade textual em um elemento que frequentemente representa digressão, assim, o caráter digressivo funciona como mecanismo para intensificar a imagem do que se apresenta, mas sem desconsiderar a função que a écfrase digressiva possa ter em cada discurso.

No caso dos lugares, épocas, modos ou personagens, é preciso que haja em sua narração fontes de argumentos a partir da beleza, da utilidade e do prazer - contemplando as funções básicas da retórica (mouere, docere, delectare) - tal como fez Homero no caso das armas de Aquiles (canto 19 da Ilíada), ao dizer que eram belas, poderosas e de aspecto admirável para os aliados, mas assustador para os inimigos.

${ }^{5}$ Hom., Od. 19.246. Tradução de C. A. Nunes. 
Hermógenes (2 d.C.) e Aftônio (4 ou 5 d.C.), também autores de progymnásmata, discorrem acerca da écfrase de maneira muito semelhante a Teão. As classificações propostas por teóricos modernos ${ }^{6}$ trazem a tipologia apresentada por Teão, estabelecendo-a como básica, salvo algumas diferenças. É evidente que a écfrase engloba inúmeras categorias em relação ao objeto descrito, isso, porém, não a limita como processo voltado exclusivamente à descrição apartada do contexto em que está inserida. Embora possa ser estabelecida como um gênero de descrição, a écfrase não restringe sua atuação apenas nesse campo; é o que ocorre na categoria mista ou composta que, como vimos, mescla ação e tempo, na realidade temos nesse caso uma écfrase narrativa - exatamente na acepção em que a narração é entendida atualmente.

Na tradição latina, a descrição é tida como um discurso amplificador que detalha para expor diante dos olhos, portanto, não há dúvida quanto à correspondência entre écfrase e descrição. Na retórica helenística, o termo ékphrasis era amplo, visto que não se limitava aos casos específicos de descrição de objetos ou obras, pois englobava a descrição de qualquer coisa, animada ou inanimada. A descrição era entendida, portanto, como um dispositivo que detalhava o seu objeto de tal maneira que pudesse ser claro o bastante para a "visualização" do mesmo.

Nicolau de Mira (séc. 3-4) é outro conhecido autor de progymnásmata, mas se diferencia dos demais por inserir a pintura e a escultura entre os objetos da écfrase (\$69), assim, ele fundamenta a écfrase de obra de arte. O mesmo autor, porém, reconhece outros tipos que tradicionalmente se enquadram na classificação apontada durante a Segunda Sofística.

A descrição é fundamental mesmo na estrutura de gêneros poéticos em que predominam a narração dos fatos, contudo, a tradição retórica ressalta a importância desse procedimento para cumprir as funções retóricas. No que concerne à evidência no discurso epidítico, o teórico Beaujour ${ }^{8}$ afirma que a descrição se estende para cumprir sua função ao máximo, pois tanto para louvar como para vituperar é um recurso necessário, dessa forma, a descrição foi adquirindo certa autonomia estética sob a denominação de écfrase.

\footnotetext{
${ }^{6}$ De acordo com Philippe Hamon (1981), os estudiosos se satisfazem com a classificação da descrição de acordo com o objeto referente: cronografia - descrição de tempo; topografia - descrição de lugar; prosopografia - descrição física de uma personagem; etopeia - descrição moral de uma personagem; prosopopeia - descrição de um ser imaginário ou alegórico; retrato - descrição física e moral; paralelo - combinação de duas descrições, por meio de semelhança ou antítese, de objetos ou personagens; hipotipose - descrição vivaz de ações, paixões, eventos físicos ou morais.

${ }^{7}$ Não encontramos a tradução dos progymnásmata desse autor, cuja consulta ficou restrita à tradução da passagem da "Écfrase" no livro de R. Webb (2009, 202-3).

${ }^{8}$ Beajour 1981.
} 
Philippe Hamon (1981) reforça a dificuldade em definir a descrição já que ela não tem um estatuto semântico - não é, por exemplo, um tropo e não pode ser definido a partir do mesmo paradigma. Contudo, é consenso para o teórico que a descrição é um dos inúmeros meios da amplificação. A mesma dificuldade ocorre também na conceituação da evidência e até mesmo da fantasia. ${ }^{9}$

Ruth Webb, renomada estudiosa do assunto, afirma que na retórica o objetivo da descrição é mais dispor o objeto diante do espectador do que propriamente explicá-lo, com a finalidade de representar além das características sensíveis do objeto também as características inteligíveis. ${ }^{10} \mathrm{~A}$ distinção entre narração e descrição como temos hoje não se observava na retórica antiga, por essa razão, a descrição, por vezes, rompia com o aspecto estático para contribuir com o efeito de vividez, tal como a menção aos fatos implícitos na cena. O dispositivo ecfrástico, portanto, remete ao discurso periegético, que guia o espectador ao redor da cena descrita, explorando ao máximo as possibilidades que a imagem encerra.

Os termos que nos remetem ao conceito da écfrase são variáveis, portanto, é possível encontrarmos menção ao processo descritivo ainda que não apareça exatamente o vocábulo "ékphrasis" ou o verbo "ekphrazo". Mesmo quando tal verbo não aparece, outros verbos podem ser associados ao processo de descrição, tais como $^{11}$ : exergéomai tem dentre seus significados "expor, relatar integralmente, apresentar"; syggrápho significa, dentre outras coisas, "descrever" e também "representar em pintura"; diagrapho - nas acepções que nos interessam pode significar "delinear ou descrever uma pessoa", etc.

Comumente, em contextos ecfrásticos, a expressão "enárgeia" aparece para tratar do aspecto de vivacidade dos textos. Dentre as acepções fornecidas no dicionário de Liddell \& Scott, a enargia significa clareza (seu primeiro significado), uma percepção clara e nítida ou mesmo uma descrição vívida no âmbito retórico. Segundo Cassin ${ }^{12}$, a écfrase é a figura retórica por excelência da enargia; nesse sentido, a enargia parece corresponder ao conceito de evidência da tradição latina, produzida por diversos procedimentos retóricos.

\footnotetext{
${ }^{9}$ Em nota, S. Dubel (1997) reúne três acepções atribuídas à enargia por Quintiliano: na discussão a respeito das paixões (6.2.32) a enargia é associada à fantasia; trata-se de uma virtude da oração (8.3.61-71); é ainda encontrada como uma virtude do discurso, portanto, um ornato (9.2.40-3).

${ }^{10}$ Cf. Webb 1999.

${ }^{11}$ Liddell \& Scott 1996, A Greek English Lexicon (Oxford: Clarendon Press). Consultamos esta obra para todos os vocábulos gregos citados adiante.

${ }^{12}$ Cassin 1997, 22.
} 


\section{2. ÉCFRASE E OUTROS PROCEDIMENTOS RETÓRICOS}

A écfrase está presente em certa medida em outros procedimentos retóricos, dos quais destacaremos alguns usualmente associados por diversos autores.

A etopeia e a prosopopeia são conceitos correspondentes a métodos descritivos presentes nos progymnásmata, os quais se convencionaram entre as modalidades ecfrásticas. Ambas estão presentes também na retórica latina, cujos preceitos corroboram a definição da Segunda Sofística.

A etopeia serve aos propósitos do gênero demonstrativo, pois quando se quer elogiar ou vituperar é necessário enumerar as qualidades ou defeitos do indivíduo, quer sejam características físicas ou morais. Logicamente, aproveita-se a descrição como forma amplificadora, uma vez que o orador ou o poeta tratará de destacar aquilo que convier ao objetivo de seu texto.

A prosopopeia se estabeleceu como figura de linguagem bastante difundida atualmente, denominando a atribuição de características humanas a seres inanimados. Na Retórica de Aristóteles (livro 3), embora não haja referência à prosopopeia, ele fornece vários exemplos de metáforas que "trazem diante dos olhos"13 - objetivo da metáfora com maior prestígio - e, para isso, a representação da ação (energei $a^{14}$ ) é muito eficiente, pode inclusive tratar-se de seres inanimados que fazem a ação. Também sobre a metáfora, Quintiliano ${ }^{15}$ reafirma a possibilidade de animar seres inanimados, pois isso torna o efeito metafórico mais sublime.

Como procedimentos da retórica antiga para imitar personagens, vivos ou mortos, animados ou não, características e discursos adequados devem ser atribuídos a cada um - a etopeia concentra-se no aspecto moral, não é mera descrição física como o que é o proposto na prosopografia. Observa-se ainda que analogamente a estas existe a idolopeia, associada a personagens já mortos e cuja descrição e atribuição de discurso torna-os animados novamente, segundo a tradição dos progymnásmata.

Um dispositivo associado à evidência é a hipotipose, que nos é apresentada por Quintiliano ${ }^{16}$ como a figura da exposição detalhada que exibe diante dos olhos; por sua vez, a hipotipose associa-se à etopeia no que concerne aos feitos da personagem retratada.

\footnotetext{
${ }^{13}$ Para todas as citações da Retórica adotamos a tradução de Manuel Alexandre Júnior; Paulo Farmhouse Alberto \& Abel do Nascimento Pena.

${ }^{14}$ Repito aqui a informação mencionada na edição utilizada com respeito à lição desse termo, adota-se comumente enérgeia, mas outra que é também aceita (por Racionero, por exemplo) é enárgeia.

${ }^{15}$ Quint. Inst. 8.6.11.

${ }^{16}$ Quint. Inst. 9.2.40.
} 
A topografia é outro mecanismo descritivo muito comum e não é apenas mencionada nos exercícios de retórica, pois está entre os tipos de descrição vívida em Quintiliano, cujo conceito está relacionado à hipotipose. Entre os latinistas, observamos a distinção da descrição de lugares reais e imaginários, esta última consiste na topotésia. ${ }^{17}$ Apesar das diferenças quanto ao referente, o processo permanece o mesmo.

A cronografia aparece na retórica grega e latina como parte do inventário ecfrástico. Embora possa parecer estranho à ideia que hoje fazemos da descrição, o detalhamento de determinadas épocas nos poemas antigos é muito frequente, pois se incluem nesse tipo as festividades.

A écfrase reflete, portanto, uma série de processos já existentes que não estavam sob essa alcunha. Como sugere Dubel (1997), parece ocorrer uma construção progressiva da autonomia da descrição, adquirida com a écfrase; a princípio, a descrição é apenas um efeito do texto, mas com a écfrase passa a integrá-lo.

É interessante observar que apesar de apresentar uma tipologia, suas espécies, por assim dizer, aparecem na tradição retórica com autonomia de figura - o que nos faria questionar se a écfrase pode ter estatuto de figura, uma vez que é composta por várias delas.

Na Retórica a Herênio, além da descrição, a demonstração (4, 68-9) corresponde igualmente ao conceito da écfrase que tem a finalidade de produzir a enargia em meio às ações narradas.

Nicolau de Mira, §70, aconselha o emprego da écfrase nos três gêneros retóricos: torna o discurso mais persuasivo no deliberativo; a amplificação que ela produz é necessária no judiciário; é suficiente para agradar ao público no epidítico.

Integrada à ação do discurso ou de caráter digressivo, a écfrase ou descrição cumpre a função de maravilhar o espectador diante do quadro que se apresenta. Em textos de cunho poético, o deleite costuma sobreporse às demais funções presentes; discursos do gênero judiciário, por sua vez, precisam comover, função que é bem desempenhada pelo caráter amplificativo da écfrase, pois os aspectos patéticos são ressaltados. No entanto, o propósito da écfrase é variável, determinado não só pelo gênero poético ou retórico, mas também por elementos próprios de cada texto.

Retornando ao outro elemento de nossa discussão, a enargia é traduzida por evidência na retórica latina, cujo adjetivo correspondente é enargês, termo que aparece frequentemente em tratados quando se menciona questões concernentes à vivacidade com que se expõem os fatos narrados. A

\footnotetext{
${ }^{17}$ Rufiniano, Schemata Dianoeas 12.
} 
definição de écfrase nos progymnásmata é a de um logos enargôs, além disso, a enargia está entre as duas virtudes da écfrase, juntamente com a saphéneia (clareza, nitidez).

O vocábulo euidentia é assim designado no dicionário de Saraiva ${ }^{18}$ : clareza, evidência; hypotypose (figura retórica). Assim como ocorre com a enargia, há em latim um adjetivo relacionado à evidência: euidens - visível, claro, patente, manifesto, evidente. Outra nomenclatura nos é dada por Quintiliano, a illustratio ${ }^{19}$ : ação de esclarecer; descrição viva e enérgica, hypotypose. Dentre as acepções para perspicuitas, mencionada por Cícero ${ }^{20}$ e Quintiliano ${ }^{21}$, temos também "evidência".

O vocábulo grego enárgeia quer dizer também "clareza, nitidez, vivacidade e percepção (visão) clara". Quintiliano define a hypotýposis ${ }^{22}$ como uma figura retórica por meio da qual um assunto era vividamente desenhado em palavras. Outro termo mencionado por Quintiliano ${ }^{23}$ e também nos exercícios de retórica é a diatýposis - figura completa e perfeita, descrição vívida.

Cassin (1997) comenta a pluralidade de termos referentes ao mesmo conceito, mas afirma que na língua latina a variação é menor, pois a enargia grega, como se observa em Cícero, corresponde canonicamente à evidência ou perspicuitas latina. Há nos textos gregos inúmeros adjetivos, além de enargês, que são encontrados em contextos da enargia.

Os tratados de Cícero provam que, ao tratar do caráter imagético de um discurso verbal, o conceito da evidência permeia a teoria implicitamente. Quando aparece em Academica, a evidência insere-se na discussão filosófica que não indica propriamente seu caráter retórico ou poético. Apenas a partir de Quintiliano temos a sistematização como mecanismo retórico e, ainda assim, não figura sob uma única denominação.

É fato que o mesmo ocorre com a enargia, mas com a particularidade de tratar-se de um vocábulo já com um histórico mais antigo, muito citado, ainda que sob a forma adjetiva. Nos diálogos de Platão e também nos tratados de Aristóteles já se observa a ocorrência do termo enárgeia em suas variações.

${ }^{18}$ F. R. dos Santos Saraiva 1927, Novíssimo Dicionário Latino-Português. Adotamos aqui esse dicionário para todas as consultas aos vocábulos latinos citados.

${ }^{19}$ Quint. Inst. 6.2.32.

${ }^{20}$ Cic. Ac. 2.; Cic. Luc.6.17.

${ }^{21}$ Quint. Inst. 8.3.61.

${ }^{22}$ Quint. Inst. 9.2.40.

${ }^{23}$ Quint. Inst. 9.2.41. 
Na Poética de Aristóteles, 1455 a, ele menciona enargestata para tratar daquilo que pode ser visto como se estivesse presente. Na Retórica, ao tratar da metáfora, o termo energeia, já citado aqui, gera dúvida se não seria na verdade enárgeia. A respeito dessa dúvida, $\mathrm{Webb}^{24}$ afirma que há mais do que mera semelhança morfológica: o efeito provocado pela enargia atua sobre o estado emocional do ouvinte; segundo Nicolau, em seus progymnásmata, é a enargia que distingue a écfrase da narração pura e simples e procura transformar o público ouvinte em espectador - funcionaria, portanto, como a energeia, cuja definição é "atividade, ação", pois age sobre o público.

Contudo, Webb declara que a crítica moderna considera tais definições um tanto ingênuas, pois ignoram as noções fundamentais da linguagem. A retórica não seria suficiente para resolver questões epistemológicas concernentes à enargia, uma vez que tal assunto concerne à filosofia. A enargia precisa, portanto, ser analisada também em chave filosófica.

Podemos dizer que o efeito da enargia está sempre presente no efeito de inúmeros tropos ou figuras, tais como a metáfora, o símile, a hipérbole, a prosopopeia, a alegoria, entre outros. Os processos adotados para se obter a enargia ou evidência são essencialmente amplificativos, pois contribuem para a exposição perspícua do assunto, além de ser mais eficiente na comoção. A enargia é capaz de comover o público, caso contrário a visualização do discurso não ocorreria, uma vez que ela depende de certa atividade anímica operada no indivíduo.

$\mathrm{O}$ resultado da enargia, portanto, requer mecanismos amplificadores, dentre os quais se encontra a écfrase ou descrição. Os métodos da amplificação contribuem não apenas para a comoção e o deleite, mas também para reforçar a credibilidade, pois permite ilustrar o discurso verbal aquilo que se torna "visível" comove mais intensamente e opera a favor da argumentação. A amplificação, portanto, é um procedimento que funciona em todos os gêneros retóricos, uma vez que é capaz de cumprir as funções correspondentes.

A metáfora possibilita trazer o discurso verbal aos olhos, representando uma ação, permitindo até mesmo a apresentação das propriedades ausentes - está patente aqui o resultado da enargia, pois ocorre a presentificação, resultado que requer o exercício da fantasia. A metáfora, portanto, desempenha a função de comover, que é ressaltada por Quintiliano ao aludir a sua capacidade de pôr diante dos olhos, além de permitir inferir outras coisas que não foram expostas a respeito do objeto metaforizado. No entanto, a função ressaltada por Aristóteles é a de ensinar porque se 
for usada apropriadamente, a metáfora produz conhecimento e ao mesmo tempo deleita, pois aprender é agradável. ${ }^{25}$ Para Cícero ${ }^{26}$, a metáfora torna as coisas mais claras e por isso deleita, além de ter muita força para comover porque afeta diretamente a visão - o sentido mais sensível -, mas só se realmente houver correspondência do termo transladado em relação ao original.

Comprova-se, portanto, que na teoria concernente à metáfora, muitos dos princípios que norteiam a enargia e, consequentemente, a écfrase, já estavam presentes na prática retórica e poética.

O símile - figura semelhante à metáfora - funciona simultaneamente como ornato e argumento quando clarifica o conteúdo veiculado. Logo, conforme a proposição de Paulo Martins ${ }^{27}$, poderíamos classificar o símile em poético e oratório; dadas as características da enargia e da écfrase, é coerente afirmar que tais recursos também operam nos dois âmbitos. Em razão da intersecção entre as duas práticas, a teoria disposta nos tratados retóricos serve para sua aplicação poética - propomos então que haja uma écfrase/descrição retórica produtora da enargia/ evidência e uma écfrase/ descrição poética, cujo efeito é o mesmo. Dessa forma, desconsideraríamos as discussões em torno do conceito que ora é gênero, ora é figura, levando em conta o contexto de produção e sua finalidade.

Observa-se a existência de uma tipologia para a enargia no tratado sobre figuras de pensamento em Quae ad Rhetores Pertinent, segundo a qual poderia ocorrer de três modos: com personagem, lugar e tempo. A conexão com a classificação da écfrase nos parece inevitável, contudo, devemos lembrar que a enargia não depende exclusivamente daquela e, por sua vez, tem estatuto de figura nos tratados latinos, o que nos remonta ao fato de poder ser produzida por outros meios.

Lembremos ainda que Quintiliano atribui à evidência outros termos como illustratio, repraesentatio, hypotýposis e diatýposis - as duas últimas numa categoria em que há transferência temporal, pois os fatos expostos podem pertencer ao passado, ao presente e ao futuro. A terminologia, portanto, gera certo conflito já que se estabelece relação da hipotipose e da diatipose com a écfrase, visto que suas ocorrências nos progymnásmata querem dizer a descrição vívida; a evidência, por sua vez, seria o resultado de tais procedimentos.

Hélio Teão fala da diatipose como descrição vívida quando discorre acerca do lugar-comum (§109), composição amplificadora de uma ação reconhecida, tal como um delito ou um ato nobre; porém, é diferente do

${ }^{25}$ Arist. Rhet. Cf. livro 3.

${ }^{26}$ Cic. De Or. 3.155-70.

${ }_{27}$ Cf. Martins 2006. 
elogio ou do vitupério porque esses tratam de personagens específicos e apresentam provas, ao passo que o lugar-comum trata unicamente de feitos e sem apresentação de provas - ele próprio se constitui uma fonte de argumentos. A diatipose finaliza o lugar-comum ao expor o delito como se se realizasse no presente, cujo efeito, portanto, é de visualização. O verbo aqui adotado é o diagrapho, que já vimos corresponder ao mecanismo da écfrase.

A écfrase é semelhante ao lugar-comum porque ambos tratam de questões comuns e gerais, no entanto, segundo Teão, diferenciam-se pelo fato de que o lugar-comum se refere a aspectos que obedecem a uma intenção prévia; ao passo que a écfrase quase sempre se refere a seres inanimados e desprovidos de vontade. A limitação da écfrase ao âmbito de objetos inanimados é incoerente se retomarmos as demais categorias já mencionadas, uma vez que pessoas também constituem objeto de descrição, bem como suas ações.

Se recordarmos a anedota de Simônides contada por Cícero no De Oratore 2.352-4, é possível também estabelecer uma relação entre a enargia e os loci: inserimos os objetos em lugares para que através da visão consigamos nos lembrar deles - o efeito de visualização é a enargia, expondo as imagens que são definidas pelas convenções e valores culturais, e quando produzida pela écfrase tem finalidade distinta do lugar-comum, pois não mais se destina à memorização, mas ao exercício da imaginação.

A écfrase ainda se distancia do lugar-comum como método amplificador, pois a função deste último deve ser cumprida por meio de imagens pontuais, ao passo que a écfrase acumula detalhes para produzir mais do que uma única imagem.

Observamos ser inegável a relação entre écfrase e enargia, visto que mesmo tentando discorrer acerca da última, acabamos retomando questões concernentes à écfrase.

Não temos a classificação da evidência nos teóricos antigos, apesar de observarmos exemplos em Quintiliano que apresentam situações diferentes, todas com o objetivo de intensificar a comoção. Autores modernos, no entanto, propõem algumas tipologias. Cassin propõe que haja dois campos de aplicação da evidência: a filosofia (o que também se observa na enargia) e a retórica. A evidência filosófica está relacionada ao que é verdadeiro, é, por sua vez, produzida pelo sentido que lhe é particular - a visão - e parte das coisas para as palavras; enquanto a retórica constrói uma relação diversa, pois os ouvidos nos servem de olhos, vai da palavra para as coisas, produzindo uma ficção. Haveria ainda um terceiro tipo originado da evidência retórica, trata-se da literária (sigo o nome adotado pela autora, desconsiderando o anacronismo do termo) - parte da palavra para a palavra, como as écfrases de Filóstrato. 
Brisson ${ }^{28}$ divide a evidência em intuitiva e discursiva se inserida apenas no âmbito filosófico: a primeira resulta da percepção imediata de uma realidade, portanto, sensível; a discursiva, por sua vez, é a consequência de uma demonstração.

\section{ANÁLISE DE EXEMPLOS}

Esboçaremos o quadro das características da écfrase a partir de alguns exemplos para expor a associação que fizemos até agora.

\subsection{Eneida}

Apesar de inúmeras ocorrências de écfrase na Eneida, o escudo de Eneias (emulação do escudo de Aquiles na Ilíada) talvez seja, juntamente com o mural do primeiro canto, a ocorrência de écfrase mais conhecida da obra, por essa razão, analisaremos exemplos menos conhecidos aqui. Destacaremos duas passagens da obra: a clâmide, no livro 5, e as portas do templo de Apolo, no livro 6.

\section{Clâmide (5.250-54)}

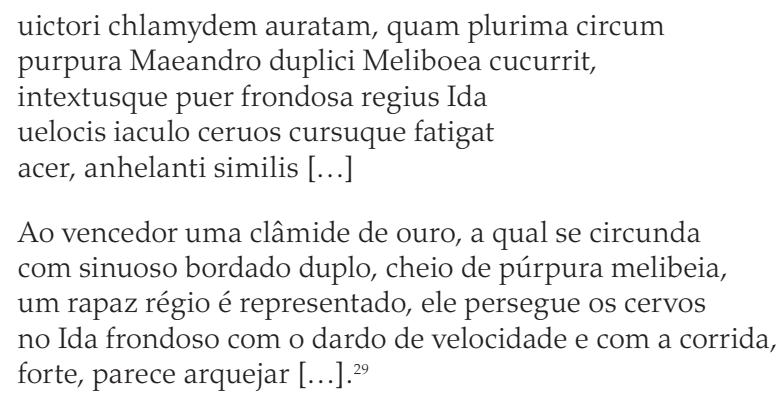

A breve écfrase detalha a imagem do manto dado como prêmio ao vencedor dos jogos em homenagem a Anquises. Embora a ação seja reduzida, a descrição serve para enaltecer o prêmio já que a imagem parece viva; vemos, de certa maneira, o rapaz caçando os cervos.

\footnotetext{
${ }^{28}$ Cf. Brisson 1997.

${ }_{29}$ Tradução própria.
} 
Por ser diminuta, o caráter é mais estático, ainda que narre a ação; a brevidade aqui contribui para dar mais vivacidade ao objeto descrito, visto que o aspecto material é tão detalhado quanto a cena gravada no manto, a enargia gerada pela pormenorização dá início ao processo imaginativo que provoca no leitor a fantasia não somente da aparência do objeto, como também da narração que o subjaz.

Temos duas ocorrências de particípio que servem como adjetivos: auratam e intextus - verbos que servem para indicar também que se trata de uma representação imagética, já que remetem para características de uma obra feita por algum artífice. Além disso, aurata nos remete a um só tempo ao material do objeto e à coloração. A cor do bordado não é apenas caracterizada como purpura, mas é ainda mais específica referindo-se à purpura Meliboea, cuja qualidade é estimada.

O emprego do presente do indicativo fatigat e do particípio presente anhelanti permitem que o leitor perceba a disposição da personagem no momento da ação, tornando menos estático o quadro apresentado.

Williams ${ }^{30}$ afirma que a écfrase do livro 5 é simplesmente decorativa, ao passo que as demais estão integradas à ação do poema. Em relação às demais écfrases do poema, de fato, essa parece deslocada, visto que as outras passagens com emprego do mecanismo ecfrástico o adotam como um meio diferenciado de realizar a narrativa, cuja temática costuma abordar a guerra de Troia ou a história romana. Entretanto, na entrada do templo de Apolo, por exemplo, narra-se um mito que não pertence ao mesmo eixo temático, mas antecipa uma importante parte da narrativa - quando Eneias saberá sobre o futuro de seu povo - e funciona, de fato, como digressão, mas realçando a expectativa em torno do que será narrado a seguir.

As écfrases na Eneida funcionam, portanto, como dispositivos que destacam algumas ações de proporções épicas e mesmo que pareçam isoladas da ação principal do poema, associam-se à temática da parte em que estão inseridas.

A écfrase do canto 5 confere destaque à passagem da premiação do vencedor dos jogos em honra a Anquises, evento também presente no poema homérico em homenagem a Pátroclo ${ }^{31}$, circunscrevendo-se na tradição da poesia épica. O tratamento dado por Virgílio é diferenciado, demonstrando a grandeza do prêmio, ao passo que, na Ilíada, os prêmios são enumerados a princípio e descritos rapidamente quando entregues.

\footnotetext{
${ }^{30}$ Williams 1960, 148.

${ }^{31}$ Hom. Il. 23.
} 
As portas do templo de Apolo (6.18-35) ${ }^{32}$

Redditus his primum terris tibi, Phoebe, sacrauit remigium alarum posuitque immania templa. In foribus letum Androgeo; tum pendere poenas Cecropidae iussi (miserum!) septena quotannis corpora natorum; stat ductis sortibus urna. Contra elata mari respondet Gnosia tellus: hic crudelis amor tauri suppostaque furto Pasiphae mixtumque genus prolesque biformis Minotaurus inest, Veneris monimenta nefandae; hic labor ille domus et inextricabilis error; magnum reginae sed enim miseratus amorem Daedalus ipse dolos tecti ambagesque resoluit, caeca regens filo uestigia. Tu quoque magnam partem opere in tanto, sineret dolor, Icare, haberes. Bis conatus erat casus effingere in auro, bis patriae cecidere manus. Quin protinus omnia perlegerent oculis, ni iam praemissus Achates adforet $[\ldots]$

Lançado a essas terras, primeiro, oh Febo, sagrou-te os remos de asas e edificou um admirável templo. Nas portas, a morte de Andrógeo; depois, os Cecrópidas, os quais foram obrigados a pagar uma pena (oh miserável!), todos os anos entregar sete corpos de filhos; ergue-se a urna nas sortes tiradas. Do lado oposto, a elevada região da Gnósia encontra-se em frente ao mar: aqui, o cruel amor do touro, Pasífaa submetida ao ardil, a espécie misturada e a prole biforme. Encontra-se o Minotauro, monumentos da nefanda Vênus. Aqui, a obra da casa e o circuito inextricável; porém, o próprio Dédalo compadeceu-se do grande amor da rainha e desvendou as trapaças da habitação e os enigmas, guiando os passos cegos com um fio. Tu também, Ícaro, terias grande parte em tamanha obra, se a dor permitisse. Duas vezes esforçara-se em representar o caso no ouro, duas vezes as mãos paternas escorregaram. Ainda continuariam percorrendo todas as coisas com os olhos se, agora, Acates não se apresentasse $[\ldots]]^{33}$

Temos poucas ações presentes nessa descrição, visto que o trabalho de Dédalo funciona como ornamento da entrada do templo. Trata-se do relato do mito do Minotauro, sua extensão é reduzida porque é uma digres-

\footnotetext{
${ }^{32}$ Verg. Ae. 6.18-35.

${ }_{33}$ Tradução própria.
} 
são que antecipa um evento importante do canto 6: a descida de Eneias ao reino dos mortos.

Embora admiráveis, o próprio herói parece desdenhar um pouco quando desvia o olhar das imagens. Considerando a écfrase do canto 8, cujo conteúdo ganhou destaque e despertou grande admiração no herói, é possível traçar um paralelo lembrando que aqui o artífice é um mortal, ao passo que no escudo é uma divindade; como o poema épico trata daquilo que é superior, poderíamos com isso justificar a preferência de Eneias pela obra de Vulcano.

Ainda que de menor extensão, alguns elementos observados geralmente em écfrases desse tipo também estão presentes aqui. A matéria-prima em que se representa o mito é referida no verso 32: in auro.

O mundo visível infere-se no verso 30 com "caeca uestigia", uma vez que o labirinto desorienta e a visão não é suficiente para encontrar a saída; e também no verso 34, com a palavra oculis quando se encerra a descrição afirmando que há ainda muito mais para ser visto.

Há duas ocorrências de apóstrofe: no princípio, quando o poeta invoca Febo (v.18) e quando o artífice Dédalo supostamente se dirige para o filho Ícaro, justificando a ausência deste na obra (v.31): "Tu também, Ícaro, terias grande parte em tamanha obra, se a dor permitisse."

O verbo posuit (v.19), no perfeito do indicativo, relaciona a arte com construção, visto que Dédalo esculpiu as imagens nas portas do templo, e a associação com a edificação nos remete à durabilidade da obra. Além disso, reforça-se a presença do insigne artífice e justifica-se a necessidade de descrever tamanha obra. O verbo effingere (v.32) refere-se ao campo semântico da representação, reafirmando tratar-se da obra de um artífice.

Sabemos que a narração do mito está localizada nas portas do templo pela expressão "in foribus" (v.20). Na própria imagem, os fatos são apresentados rapidamente, mas mesmo assim há certa orientação espacial; observa-se que a Gnósia é disposta em frente ao mar ("contra mari" - v.23) e o advérbio hic aparece duas vezes (v.24 e 27) localizando determinado elemento da imagem.

Desde o começo da descrição, a partir do verso 20, vemos desfilar uma série de personagens que compõem o mito do Minotauro, que passam de maneira tão breve quanto a enumeração de personagens durante a batalha. Ainda assim, a breve écfrase é suficiente para resumir o mito e possibilitar ao leitor um rápido desvio da ação principal por meio da vivência dessa narrativa. 


\subsection{Historiografia}

É possível analisar a descrição em textos historiográficos sob os preceitos da evidência; nota-se que a écfrase se processa de maneira distinta em cada obra porque apresenta finalidades distintas.

Predomina a etopeia nas monografias históricas de Salústio, uma vez que o autor discute um fato histórico demonstrando o êthos, ou seja, a disposição moral das personagens que fazem parte dos acontecimentos.

O elogio ou vitupério compõem, logicamente, o inventário do gênero demonstrativo, cuja função principal é deleitar. Os retratos constituem exemplo desse gênero e servem bem aos propósitos da monografia em que se narra um único acontecimento e se apresenta as personagens envolvidas de modo pormenorizado para justificar o papel desempenhado por cada uma delas na ação.

Retoricamente, a monografia poderia então ser considerada como gênero demonstrativo, uma vez que sua função primordial seria deleitar, segundo os preceitos de Cícero em sua carta a Luceio. ${ }^{34}$ Ao narrar um único evento, expõe-se os participantes de maior relevância nos acontecimentos de maneira que alguns sejam elogiados e outros vituperados - as obras de Salústio formam retratos que são produtos desse gênero, opondo as figuras virtuosas às viciosas.

Destaquemos, portanto, a primeira passagem do capítulo 6 da Guerra de Jugurta que produz um retrato de Jugurta, mas não se trata de mero detalhamento das características físicas, na realidade, é um retrato moral, ou como já observamos, a etopeia.

Os elementos que servem para a caracterização são variados. Para a construção do êthos, Jugurta reúne características de ordens distintas, ainda que nessa obra o aspecto moral tenha destaque. Logo na primeira parte vemos reunidos diversos elementos: fisicamente é "superior nas forças, de bela aparência", o ânimo "muito rico em engenho, não se entregou à corrupção do luxo, tampouco da inércia" e a fortuna está implícita quando se afirma ser "querido por todos".

Embora predomine a caracterização física no começo, o que mais se destaca são as qualidades a ele atribuídas porque entendemos que são suas virtudes morais que agradam aos outros: era inteligente, não era corrupto, tampouco ocioso, além disso, era corajoso e agia mais do que falava.

A enumeração - um recurso típico da amplificação - está presente em toda a descrição de Jugurta. Embora aqui o caráter da écfrase seja está- 
tico em relação às ocorrências da Eneida, ao elencar as atividades praticadas por ele, quase presenciamos as ações:

Qui ubi primum adoleuit, pollens uiribus, decora facie, sed multo maxume ingenio ualidus, non se luxu neque inertiae corrumpendum dedit, sed, uti mos gentis illius est, equitare, iaculari, cursu cum aequalibus certare; et cum omnis gloria anteiret, omnibus tamen carus esse; ad hoc pleraque tempora in uenando agere, leonem atque alias feras primus aut in primis ferire: plurumum facere, minumum ipse de se loqui... ${ }^{35}$

Logo que ele (Jugurta) cresceu, superior nas forças, de bela aparência, mas, sobretudo, muito rico em engenho, não se entregou à corrupção do luxo, tampouco da inércia, mas, como é de costume daquele povo, cavalgava, lançava o dardo, disputava na corrida com os da mesma idade; e excedia a todos em glória, era, contudo, querido por todos; além disso, levava a maior parte do tempo caçando, era o primeiro ou estava entre os primeiros a ferir o leão e outras feras: fazia o máximo e falava o mínimo de si... ${ }^{36}$

A descrição de Jugurta é constituída também pela reflexão de Micipsa, cuja perturbação indica a presença não mais de um êthos, mas de um páthos, a partir do qual temos conhecimento de seu medo de perder o reino, o que serve para realçar a força de Jugurta, já querido pelos númidas.

Trata-se da descrição do caráter de uma personagem real, portanto, a etopeia funciona muito bem na monografia, pois se concentra nas figuras mais importantes de um evento, de maneira que seja possível inferir suas atitudes a partir de suas disposições morais, ainda que a caracterização seja breve.

No caso das monografias de Salústio, detalhar o êthos é indispensável, uma vez que a oposição entre vício e virtude é fundamental para compreender as ações e suas consequências históricas. Desse modo, cumpre-se a função retórica de ensinar, já que tais obras têm caráter exemplar. $\mathrm{Na}$ conclusão de sua pesquisa, Renato Ambrosio ${ }^{37}$ destaca a relação entre o discurso demonstrativo e os demais, portanto, a monografia, embora considerada gênero demonstrativo, cumpre bem as funções atribuídas a outros, assim como o docere: uma vez que há uma tradição retórica de aproximar o gênero demonstrativo do deliberativo, visto que são úteis nos negócios públicos, tal como o elogio e o vitupério durante o julgamento.

$\mathrm{O}$ retrato, por seu aspecto digressivo, constitui um recurso eficiente para deleitar já que interrompe a narração e desperta o interesse do leitor. Embora a narração seja suspensa momentaneamente, a digressão não foge

\footnotetext{
${ }^{35}$ Sal. Jug. 6.

${ }^{36}$ Tradução própria.

${ }^{37}$ Ambrosio 2005, 152.
} 
aos propósitos do autor que a um só tempo reforça sua argumentação e produz certa expectativa no leitor.

As formas verbais na descrição de Jugurta pertencem a tempos variados, sem predominância de um único, mas nos desperta a atenção a presença das formas nominais ultrapassando em quantidade as formas conjugadas dos verbos. Destaca-se o infinitivo presente, indispensável em passagens descritivas que elencam as atividades executadas pelo indivíduo. O particípio perfeito e também o particípio presente ocorrem, com menor frequência, auxiliando na caracterização da personagem, pois alguns aspectos são implicados sem demonstração de uma ação direta. ${ }^{38}$ Isso contribui para a brevidade da narrativa da monografia, pois tudo deve convergir para a ação principal; portanto, as caracterizações contribuem para o percurso narrativo, mas como digressões e não devem ocupar grande parte da narração.

A antiga historiografia objetivava a verossimilhança, apresentando aparência de verdade e não os fatos em si, segundo Walker ${ }^{39}$ tal resultado se comprovava pelo grau de visualização percebido pelo leitor. A enargia é o aspecto que deve predominar no texto, mas os procedimentos para produzi-la são variáveis. Aqui é possível reforçar a distinção entre a écfrase e a enargia, visto que a última é característica apropriada aos textos, para reforçar os efeitos esperados; a écfrase é um típico processo pelo qual se forma a enargia, uma vez que a descrição simples e sem ornamentação pode falhar em produzir o efeito de visualização.

\section{CONSIDERAÇÕES FINAIS}

A associação do meio visual com a linguagem verbal norteia o princípio da evidência ou da enargia em razão da força atribuída ao sentido da visão. A écfrase constitui na retórica o procedimento adequado à presentificação do discurso e as três funções retóricas são muito bem cumpridas pela écfrase acompanhada da enargia.

O caráter digressivo da descrição pode nos levar equivocadamente a pensar que o deleite seja o fim mais apropriado, entretanto, observamos que opera também o docere e o mouere dependendo do contexto na qual se insere. No que concerne à Eneida, por exemplo, se imaginarmos a época

${ }^{38}$ Breve comentário acerca do uso do particípio presente na historiografia grega encontra-se em Walker 1993, 365.

${ }^{39}$ Walker 1993, 374. 
de sua composição, é inevitável a conexão entre o conteúdo da obra e o elogio a Augusto - o tema das écfrases desse poema costuma remeter à grandiosidade da estirpe de Eneias, cujo protagonista no canto 8 é Otávio. A exaltação de Augusto deleita e comove o público, que verá na sua figura um homem superior e representante dos romanos.

O emprego na monografia mostrou-se importante para ensinar trazendo modelos de conduta; as uitae, por sua vez, sem caráter exemplar, discorrem a respeito de uma figura louvável, como é o caso do Divino Júlio de Suetônio.

Em todos os casos, a écfrase ou descrição constitui o dispositivo básico não apenas para detalhar, mas para ressaltar os aspectos desejados pelo autor. Nas ocorrências de maior extensão, são produzidos mais do que retratos estáticos, é possível entrever ações, desejos, emoções, enfim, elementos que vemos hoje como típicos da narração.

Por fim, ressaltemos que as discussões em torno da écfrase e sua diferenciação com os demais conceitos a ela relacionados são controversas em razão da profusão terminológica apresentada por teóricos antigos e também pela ideia que os estudiosos modernos fazem de descrição, isolando-a da narração. Assim, é comum vermos a enargia ou evidência serem definidas de maneira semelhante à écfrase, porém, percebemos que não são exatamente equivalentes, ainda que todas convirjam para resultar na imagem verbal de uma narrativa ou de um objeto, quer seja real ou fictício.

\section{REFERÊNCIAS}

Ambrosio, R. 2005. De Rationibus Exordiedi. Os princípios da história em Roma. São Paulo: Humanitas/Fapesp.

Beajour, M. 1981. "Some Paradoxes of Description." Yale French Studies 61:27-59.

Brisson, L. 1997. “L'intelligible comme source ultime d'évidence chez Platon.” In Dire L'Évidence, editée par C. Levy et L. Pernot, 95-111. Paris: L'Harmattan.

Cassin, B. 1997. "Procedures Sophistiques pour construire l'évidence." In Dire L'Évidence, editée par C. Levy et L. Pernot, 15-29. Paris: L'Harmattan.

Dubel, S. 1997. "Ekphrasis et enargeia: la description antique comme parcours". In Dire L'Évidence, éditée par C. Levy et L. Pernot, 249-64. Paris: L'Harmattan.

Hamon, P. 1981. "Rhetorical Status of Descriptive." Yale French Studies 61:1-26. (Tradução de Patricia Baudoin.)

Hansen, J. A. 2006. "As categorias epidíticas da ékphrasis." Revista da Universidade de São Paulo 71:85-105.

Lausberg, H. 1966. Manual de Retórica Literaria 1-3. Trad. José Pérez Riesco. Madrid: Editorial Gredos. 
Martins, P. 2006. “Tropos na Eneida e uma imagem metafórica." In I Simpósio de Estudos Clássicos, organizado por M. M. dos Santos, 91-118. São Paulo: Humanitas.

Rufiniano, Julio. 1868. Schemata Dianoeas quae ad Rhetores Pertinent. In Rhetores Latini Minores. Ex Codicibus Maximam Partem Primum Adhibitis, edited by K. Halm. Leipzig: Teubner. Dubuque: Iowa-Reprint Library.

Walker, A. D. 1993. "Enargeia and the Spectator in Greek Historiography." Transactions of the American Philological Association 123:353-77.

Webb, R. 1997. "Mémoire et imagination: les limites del'enargeia dans la théorie rhétorique grecque." In Dire l'evidence, éditée par C. Levy et L. Pernot, 229-48. Paris: L'Harmattan.

Webb, R. 1999. "The Aesthetics of Sacred Space: Narrative, Metaphor, and Motion in 'Ekphraseis' of Church Buildings." Dumbarton Oaks Papers 53:59-74.

Williams, R. D. 1960. "The Pictures on Dido's Temple." In Classical Quarterly 10(3-4):145-51.

Abstract. Ékphrasis is a descriptive device used in rhetorical and poetic texts since Classical Antiquity which brings the described contents before the eyes through strategies to make vivid images. It is usually related to other rhetorical procedures which also contribute to create the same effect, such as enárgeia and euidentia. Trying to solve the doubts related to ékphrasis' definition, and to understand its relation with other rhetorical figures, it is presented here a brief research based on ancient rhetorical texts, such as Aristotle, progymnásmata, Cicero and Quintilian, and also on recente studies about the subject. Some examples with ékphrasis in ancient texts are analysed to verify the procedures which make the verbal speech present to the eyes.

Keywords. Ékphrasis; euidentia, enárgeia; phantasia; Rhetoric. 